\title{
Development of some male characteristics supported by oestrone but not dehydroepiandrosterone in the boar
}

\author{
W. D. Booth \\ A.R.C. Institute of Animal Physiology, Animal Research Station, 307 Huntingdon Road, \\ Cambridge CB3 0JQ, U.K.
}

\begin{abstract}
Summary, Prepubertally castrated boars received subcutaneous injections twice weekly, from 13 to 35 weeks of age, of dehydroepiandrosterone $(2 \mathrm{mg} / 5 \mathrm{~kg})$ or oestrone $(1 \mathrm{mg} / 5 \mathrm{~kg}$ ). Dehydroepiandrosterone did not support the growth and secretory activity of the accessory organs, or induce copulatory behaviour. However, oestrone caused hypertrophy of the prostate, seminal vesicles and bulbourethral glands which was due to an increase in fibrous stromal tissue and not to the secretory epithelium. Oestrone also induced some male mating behaviour patterns in the presence of an oestrous gilt, although penile extrusion and ejaculation did not occur. The morphological and behavioural effects of the steroid treatments were supported by steroid profiles in blood plasma as seen in comparison with androgen and oestrogen values of intact and untreated castrated boars. It is concluded that oestrogen in the intact boar might enhance the secretion of the accessory organs by affecting the neural control of the secretory processes rather than by increasing the amount of secretory epithelium in the glands.
\end{abstract}

\section{Introduction}

A variety of steroids are produced by the pig testis. Although studies have been carried out to determine the physiological significance of some of these steroids (see review by Booth, 1982), the role of others is largely unknown. The 5-ene unsaturated $\mathrm{C}_{19}$ steroids dehydroepiandrosterone (DHA) and 5-androstene-3 $\beta, 17 \beta$-diol (5-androstenediol), and their respective sulphate conjugates are present in high concentrations in porcine testicular tissue (Ruokonen \& Vihko, 1974; Booth, 1975). Furthermore, large quantities of these steroids, particularly the sulphate conjugates, are secreted by the boar testis (Baulieu, Fabre-Jung \& Huis in't Veld, 1967; Raeside \& Howells, 1971; Setchell, Laurie, Flint \& Heap, 1983). There is evidence indicating that DHA and 5-androstenediol may be important precursors of testosterone in the pig testis (Ruokonen, 1978) as has been suggested for the testes of dogs (Yamaji, Motohashi, Tanioka \& Ibayashi, 1968; Oh \& Tamaoki, 1973) and men (Vihko \& Ruokonen, 1975). However, there is also evidence indicating that, in the boar, 5-ene unsaturated $\mathrm{C}_{19}$ steroids may be important prohormones for testosterone in extragonadal tissues such as the submaxillary gland (Booth, 1977) and the accessory sex organs (Booth, 1980). Administration of 5-androstenediol to prepubertally castrated boars $(2 \mathrm{mg} / 5 \mathrm{~kg}$ ) maintained the accessory organs in a manner comparable to that produced by the same amount of testosterone (Booth, 1980).

The boar testis also produces large amounts of oestrogen (Velle, 1966). Oestrone sulphate is the predominant oestrogen in the peripheral plasma of the boar (Booth, 1980; Claus \& Hoffmann, 1980; Setchell et al., 1983), together with smaller amounts of unconjugated oestrone and oestradiol (Booth, 1980). All these oestrogen fractions in boar plasma are present in higher concentration than those in the plasma of oestrous gilts (Henricks, Guthrie \& Handlin, 1972). Studies aimed at defining a role for oestrogen in the boar are contradictory. Joshi \& Raeside (1973) have shown that 
oestrogen acts synergistically with testosterone to enhance both the secretory activity of the accessory sex organs and sexual behaviour in boars castrated after puberty. On the other hand, Booth (1980) was unable to show a synergistic effect of testosterone or 5-androstenediol in combination with oestrone on the development of male characteristics in prepubertally castrated boars, even though the amounts of steroid administered were comparable to those used by Joshi \& Raeside (1973).

The aims of the present investigation, therefore, were to find out whether (1) DHA has significant androgenic activity in the boar, and (2) oestrone, when administered alone to prepubertally castrated boars, has effects which were not manifested when the oestrogen is administered in combination with androgen (Booth, 1980).

\section{Materials and Methods}

\section{Animals and treatments}

Ten Large White boars from two litters were castrated at 4 weeks of age and weaned at 7 weeks of age. At 8 weeks of age the pigs were housed in two covered pens, each containing 5 pigs randomized with respect to bodyweight, were fed twice daily $(0.5 \mathrm{~kg}$ food $/ 25 \mathrm{~kg}$ bodyweight $)$ with Sowfeed Red Rolls 417 (BOCM, Silcock, Basingstoke, Hampshire, U.K.) consisting of $2.5 \%$ oil, $16 \%$ protein and $6.5 \%$ fibre supplemented with vitamins $\mathrm{A}, \mathrm{D}$ and $\mathrm{E}$. The pigs were first weighed at 12 weeks of age and then weekly until slaughter at 35 weeks of age. During this 22 -week period each group of 5 pigs was assigned to one of two steroid treatments. The pigs received twice weekly (Monday and Thursday) subcutaneous injections of DHA $(2 \mathrm{mg} / 5 \mathrm{~kg})$ as a suspension in arachis oil $(20 \mathrm{mg} / \mathrm{ml})$ (Group A), or oestrone $(1 \mathrm{mg} / 5 \mathrm{~kg})$ suspended in arachis oil $(10 \mathrm{mg} / \mathrm{ml})$ (Group B). The amounts of steroid injected and the duration of the steroid treatments were comparable to those described previously for $\mathrm{C}_{19}$ steroids and oestrone (Booth, 1980). When the pigs were 22 weeks old, each group was rehoused in two partly covered pens so that there were 2 pigs in one pen and 3 pigs in the other pen.

During the last month of steroid treatment, 4 blood samples were collected at weekly intervals from the anterior vena cava into heparinized syringes. Blood collections 1,3 and 4 were taken on a Tuesday, one day after a steroid injection. However, blood sample 2 was collected on a Wednesday 6 days after an injection of a double dose of steroid to compensate for the unavoidable absence of an injection on the Monday preceding the blood collection. The blood was centrifuged and the plasma stored at $-20^{\circ} \mathrm{C}$ until required for steroid analysis. Single blood plasma samples were also available from castrated boars (Group C) and intact boars (Group D) of an age comparable to that of the pigs in Groups A and B; the plasma samples had been assayed previously for unconjugated androgen and oestrogen and the values related to the development of the accessory sex glands and submaxillary glands. Histological data for these pigs are included for the first time in the present communication (P1. 1, Figs 3 \& 4; P1. 2, Figs 9-12) to provide a comparison with previously published data on these animals (Booth, 1980) and those obtained in the present study.

\section{Steroid determinations}

The radioimmunoassay for unconjugated androgen was as previously described by Booth \& Baldwin (1980) using an antiserum which cross-reacted primarily with testosterone $(100 \%)$ and $5 \alpha$ dihydrotestosterone $(100 \%)$; the cross-reaction with DHA was $1.5 \%$. Total unconjugated oestrogen was determined by radioimmunoassay as previously described by Newcomb, Booth \& Rowson (1977), where the cross-reaction of oestrone with the antiserum was $55 \%$. The radioimmunoassay for DHA and DHA sulphate was carried out using the antiserum described by Smith et al. (1975). The assay method was similar to that described by Pashen, Sheldrick, Allen \& Flint (1982), and used for pig plasma by Setchell et al. (1983). The minimum amounts of DHA and DHA sulphate 
that were measurable were about $10 \mathrm{pg}$ and $50 \mathrm{pg}$ respectively. The within-assay coefficients of variation were DHA $10.2 \%$ and DHA sulphate $2.9 \%$; the between-assay coefficients of variation were $19.8 \%$ for DHA and $13.3 \%$ for DHA sulphate.

\section{Target organs for testicular steroids}

After slaughter the genital tract and submaxillary glands were removed, and the prostate, seminal vesicles, bulbourethral glands and submaxillary glands were weighed; pieces of prostate, seminal vesicles and submaxillary glands were fixed in Bouin's fluid for histology. The seminal vesicles were stored at $-70^{\circ} \mathrm{C}$ pending the analysis of zinc as described by Booth \& Baldwin (1980).

A carcass evaluation, including a general assessment and hand joint dissection, was carried out by the Meat and Livestock Commission, Bletchley, U.K., to determine any possible anabolic effects of the steroid treatments.

\section{Behaviour}

During the last week of steroid treatments, each pig in Groups A and B was introduced individually on 3 separate days to a neutral pen housing a gilt (2nd day of oestrus), and expressions of mating and aggressive behaviour were noted during a 5-min period.

\section{Results}

\section{Body weight and steroid-dependent glands}

A mean daily weight gain of $0.57 \mathrm{~kg} /$ day was found for pigs in Groups A and B. The only significant difference $(P<0.05)$ between the carcasses of these two groups was the higher lean content in the hand joint of the pigs receiving oestrone $(59 \cdot 4 \%$ lean, $19 \cdot 2 \%$ fat $)$ compared with that in the pigs receiving DHA (56.5\% lean, $22.3 \%$ fat). Enlargement of the teats was first seen at 16 weeks of age in pigs in Group B and persisted until slaughter.

Treatment with DHA (Group A) did not support the growth and development of the accessory sex organs (Table 1; Pl. 1, Fig. 1; P1. 2, Figs 5 \& 6). Unfortunately, it was only realized at slaughter that one of the animals in Group A was a unilateral castrate with a retained abdominal testis weighing $144 \mathrm{~g}$. The data for this pig are shown separately in Tables 1-3 to provide a comparison with the data for the bilaterally castrated pigs receiving steroids, and also to demonstrate the maintained endocrine activity of the cryptorchid testis (Table 2) as seen through its effects on the development of accessory sex organs and submaxillary glands (Table 1).

Table 1. Mean \pm s.e.m. body weights and organ weights (mean single glands) in boars castrated prepubertally and receiving DHA (Group A) and oestrone (Group B) and in untreated castrated boars (Group C) and intact boars (Group D)

\begin{tabular}{|c|c|c|c|c|c|c|}
\hline \multirow[b]{2}{*}{ Group } & \multirow[b]{2}{*}{ No. of pigs } & \multirow[b]{2}{*}{$\begin{array}{c}\text { Body wt } \\
(\mathrm{kg})\end{array}$} & \multicolumn{4}{|c|}{ Gland weights (g) } \\
\hline & & & Prostate & $\begin{array}{l}\text { Seminal } \\
\text { vesicle }\end{array}$ & $\begin{array}{l}\text { Bulbo- } \\
\text { urethral }\end{array}$ & $\begin{array}{l}\text { Submaxillary } \\
\text { salivary }\end{array}$ \\
\hline A & $\begin{array}{l}4 \\
1^{*}\end{array}$ & $121 \pm \frac{5 \cdot 16}{137}$ & $\begin{array}{c}0.73 \pm 0.19 \\
14 \cdot 9\end{array}$ & $0.57 \pm \frac{0}{139}$ & $\begin{array}{c}2 \cdot 22 \pm 0 \cdot 13 \\
95 \cdot 0\end{array}$ & ${ }_{35 \cdot 2}^{18 \cdot 2 \pm 1 \cdot 01}$ \\
\hline B & 5 & $121 \pm 3.00$ & $15 \cdot 3 \pm 3.00$ & $8.74 \pm 1 \cdot 14$ & $11.9 \pm 2.01$ & $18.7 \pm 0.48$ \\
\hline $\mathrm{C} \dagger$ & 3 & $86 \pm 0.03$ & $0.56 \pm 0.03$ & $0.94 \pm 0.11$ & $5.29 \pm 0.14$ & $20.3 \pm 1.58$ \\
\hline $\mathrm{D} \dagger$ & 4 & - & $11.8 \pm 1.27$ & $211 \pm 5.51$ & $122 \pm 2.60$ & $54.9 \pm 0.56$ \\
\hline
\end{tabular}

* Unilaterally castrated, unilateral cryptorchid. Data for this animal have not been included in the mean data for the remaining 4 pigs in Group A.

† Data from Booth (1980). Accessory sex glands and submaxillary glands were obtained from fewer pigs in Groups $\mathrm{C}$ and $\mathrm{D}$ than provided blood plasma samples (see Table 2). 
Table 2. Mean \pm s.e.m. concentrations of steroids in the peripheral plasma of boars castrated prepubertally and receiving DHA (Group A) and oestrone (Group B) and in untreated castrated (Group C) and intact (Group D) boars

\begin{tabular}{cccccc}
\hline Group & $\begin{array}{c}\text { No. of } \\
\text { pigs }\end{array}$ & $\begin{array}{c}\text { Unconjugated } \\
\text { DHA (ng/ml) }\end{array}$ & $\begin{array}{c}\text { Sulphate-conjugated } \\
\text { DHA (ng/ml) }\end{array}$ & $\begin{array}{c}\text { Unconjugated } \\
\text { oestrogen }(\mathrm{pg} / \mathrm{ml})\end{array}$ & $\begin{array}{c}\text { Unconjugated } \\
\text { androgen }(\mathrm{ng} / \mathrm{ml})\end{array}$ \\
\hline A & 4 & $0.34 \pm 0.03$ & n.d. & - & $0.09 \pm 0.02$ \\
& $1^{*}$ & $0.93 \pm 0.54$ & $20.8 \pm 3 \cdot 25$ & - & $0.73 \pm 0.29$ \\
B & 5 & - & - & $1532 \pm 228$ & $0.07 \pm 0.00$ \\
C & 5 & $0.08 \pm 0.01$ & n.d. & $21.7 \pm 4.76 \dagger$ & $0.14 \pm 0.02 \dagger$ \\
D & 5 & $1.36 \pm 0.36$ & $154 \pm 6.00$ & $352 \pm 6.45 \dagger$ & $8.13 \pm 2.04 \dagger$ \\
\hline
\end{tabular}

Values are based on the means of 3 plasma samples per animal collected at weekly intervals during the last month of treatment (Groups A and B). Values for Groups C and D are based on single samples for each pig.

n.d. none detected.

* Unilaterally castrated, unilateral cryptorchid. Data for this animal have not been included in the mean data for the remaining 4 pigs in Group $A$.

† Some data for Groups C and D extracted from that published previously (Booth, 1980).

In the pigs in Group B there was considerable hypertrophy of the prostate and to a lesser extent the seminal vesicles and bulbourethral glands; the muscle surrounding the urethra was also welldeveloped (Table 1; Pl. 1, Fig. 2). Histology of the prostate and seminal vesicles in these animals (P1. 2, Figs $7 \& 8$ ) showed that it was the stromal tissue that was hypertrophied and not the secretory epithelium. However, the bulbourethral glands of these oestrogen-treated pigs contained a yellowish secretion, and in 2 animals there was a viscous secretion, indicating that some secretory activity was present although the condition of the secretory epithelium was not determined histologically.

\section{PLATE 1}

Accessory sex organs of castrated boars treated with DHA and oestrone compared with the same organs of an untreated boar and an intact boar. Seminal vesicle (SV), prostate (P), bulbourethral gland (Bu), muscle surrounding the urethra (MU).

Fig. 1. Castrated boar receiving DHA. Note small accessory sex organs similar to those in the untreated castrated boar (Fig. 3).

Fig. 2. Castrated boar receiving oestrone. Note hypertrophied accessory sex organs and welldeveloped muscle surrounding the urethra.

Fig. 3. Untreated castrated boar. Note small accessory sex organs.

Fig. 4. Untreated intact boar. Note well-developed accessory sex organs.

PLATE 2

Fig. 5. Prostate of castrated boar receiving DHA. Note limited development of the secretory epithelium (se). $\times 256$.

Fig. 6. Seminal vesicle of castrated boar receiving DHA. Note similar appearance to Fig. 5 . $\times 256$.

Fig. 7. Prostate of castrated boar receiving oestrone. Note limited development of secretory epithelium (se) and extensive fibrous stromal tissue (fs). $\times 256$.

Fig. 8. Seminal vesicle of castrated boar receiving oestrone. Note similar appearance to Fig. 7 . $\times 256$.

Fig. 9. Prostate of untreated castrated boar. Note similar appearance to Fig. $5 . \times 256$.

Fig. 10. Seminal vesicle of untreated castrated boar. Note similar appearance to Fig. $6 . \times 256$.

Fig. 11. Prostate of mature intact boar. Note extensive development of secretory epithelium (se). $\times 256$.

Fig. 12. Seminal vesicle of mature intact boar. Note convolutions of well-developed secretory epithelium (se). $\times 256$. 
PLATE 1

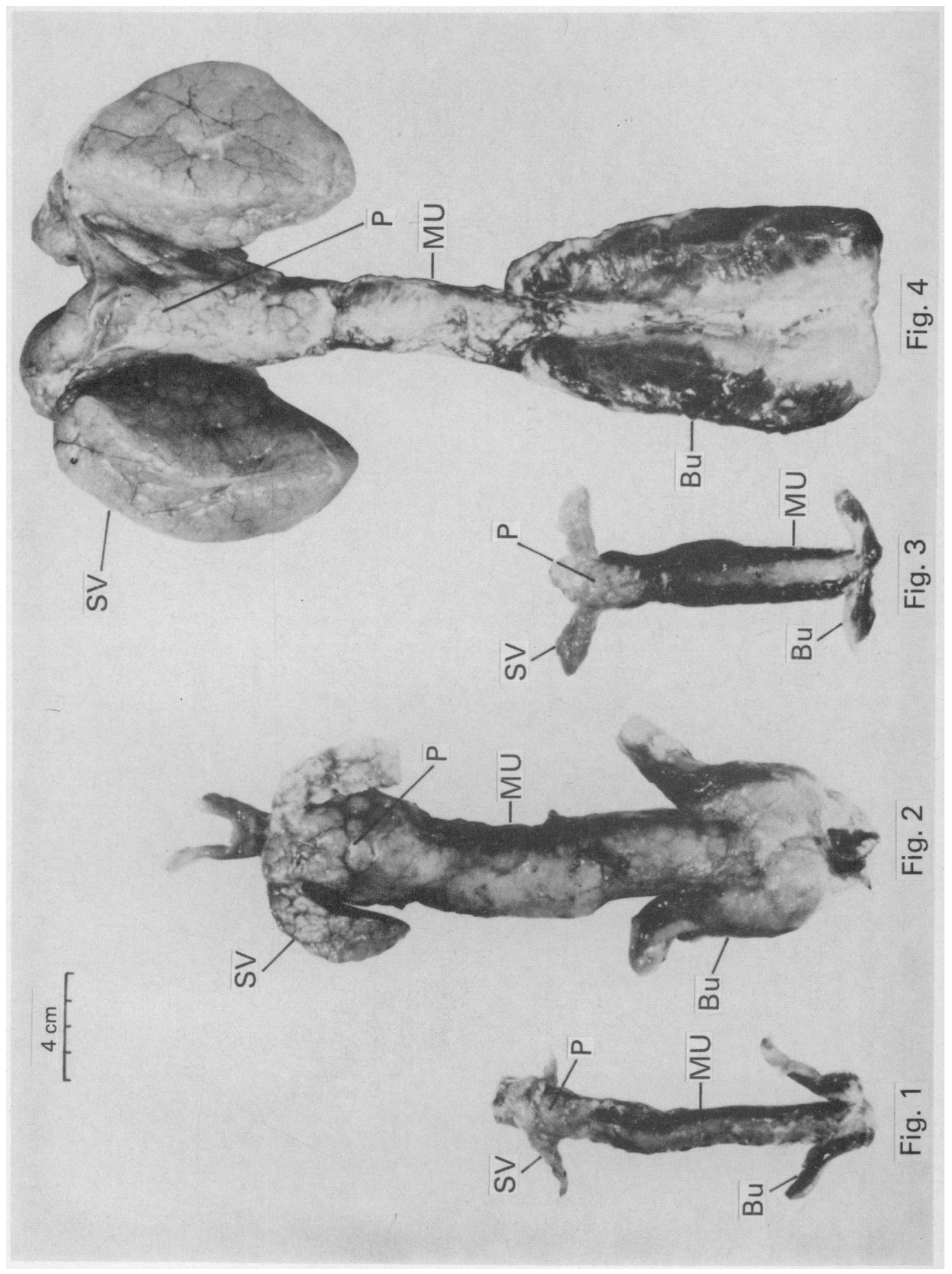

(Facing p. 12) 

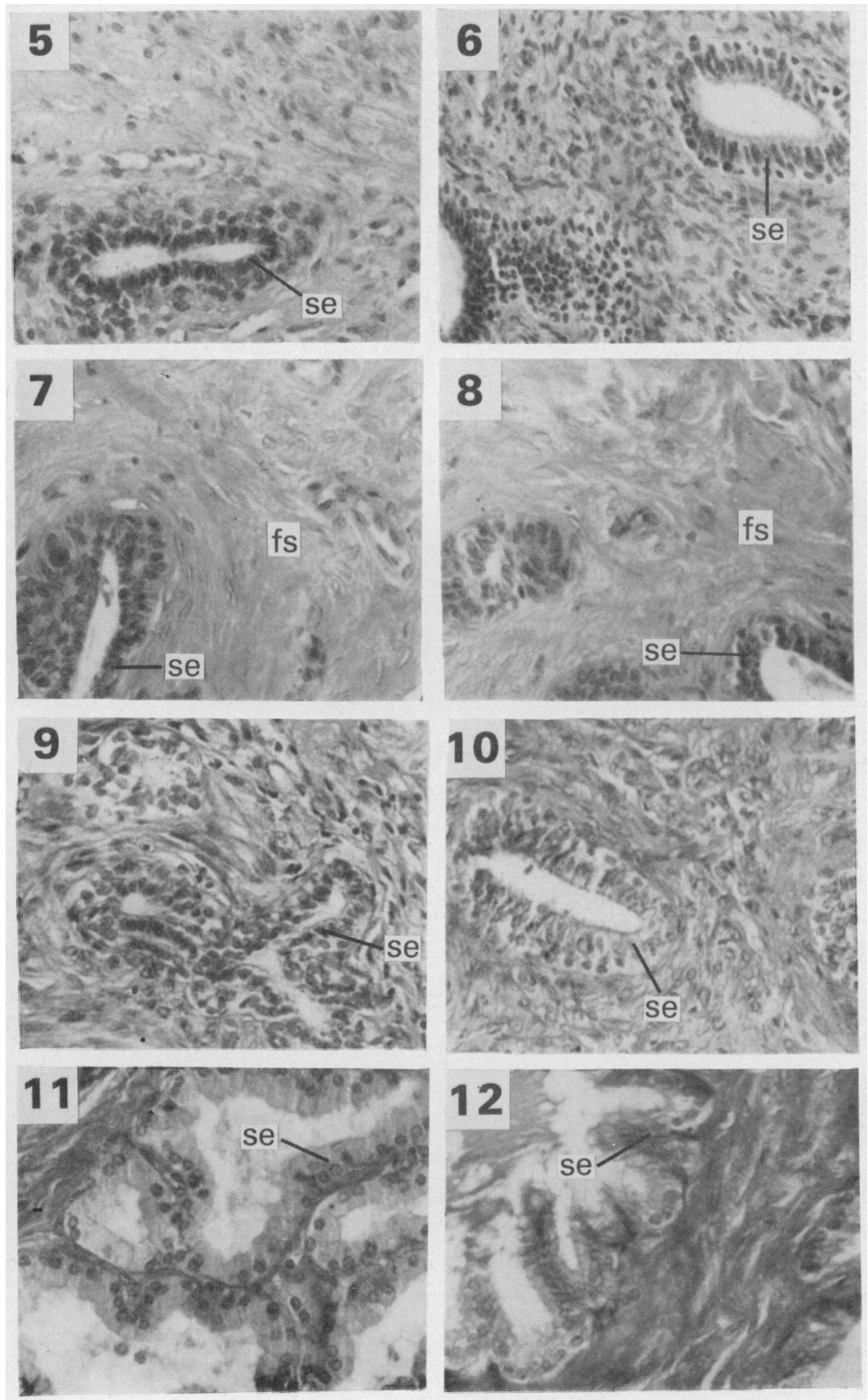
Zinc levels (mean \pm s.e.m.) in the seminal vesicles of all pigs were very low (Group A, 7.02 \pm $0.57 \mu \mathrm{g}$ and $0.008 \pm 0.002 \mathrm{mg} /$ glands; Group B, 4.85 $\pm 0.54 \mu \mathrm{g}$ and $0.09 \pm 0.02 \mathrm{mg} / \mathrm{glands}$ ).

Neither the weights nor the histological appearance of the submaxillary gland were affected by the treatments with DHA or oestrone.

\section{Steroids in peripheral plasma}

The results of the steroid assays are shown in Table 2. DHA sulphate was undetectable in the plasma of DHA-treated pigs (Group A) and untreated castrated boars (Group C). Furthermore, unconjugated androgen values were similar in Groups $A$ and $B$, and were as low as those in Group $\mathrm{C}$ animals.

The mean hormone concentrations in pigs in Groups A and B at the second blood collection were $0.025 \mathrm{ng} \mathrm{DHA} / \mathrm{ml}$ and $694 \mathrm{pg}$ oestrone $/ \mathrm{ml}$, respectively; these values are much lower than those obtained for the other 3 blood collections and are not included in the mean data in Table 2.

\section{Behaviour}

Pigs treated with DHA (Group A) only champed small amounts of saliva accompanied by some investigative behaviour of the gilt (Table 3). Only one pig other than the unilateral cryptorchid pig showed any indication of being sexually aroused, and in one test one pig showed some aggression towards the gilt. In two tests, 2 pigs provoked aggression in the gilt while they themselves remained passive. In contrast, the pigs treated with oestrone (Group B) were invariably aroused when introduced to the gilt; they champed copious amounts of saliva, nudged and sometimes mounted the gilt (Table 3). The pigs displaying the most boar-like behaviour in the presence of the oestrous gilt were also the largest pigs in the group. During mounting of the gilt they displayed vigorous pelvic movements and movements of the penis in the preputial sheath, but extrusion of the penis was not achieved. The smallest pigs in this group tended to elicit an aggressive response from the oestrous gilt, or show aggression towards the gilt.

Table 3. Behaviour displayed in the presence of an oestrous gilt by pigs castrated prepubertally and receiving DHA or oestrone

\begin{tabular}{lllll}
\hline \multirow{2}{*}{ Group } & & \multicolumn{3}{c}{ Tests } \\
\cline { 3 - 4 } & Behaviour & 1st & 2nd & 3rd \\
\hline A (DHA) & Some saliva & $1 / 4$ & $3 / 4$ & $4 / 4$ \\
& Nudged gilt & $0 / 4$ & $2 / 4$ & $4 / 4$ \\
& Mounted gilt & $0 / 4$ & $0 / 4$ & $0 / 4$ \\
& Pelvic thrusts & $1 / 4$ & $0 / 4$ & $0 / 4$ \\
B (oestrone) & Penis extruded & $1 / 4$ & $1 / 4$ & $1 / 4$ \\
& Copious saliva & $5 / 5$ & $5 / 5$ & $5 / 5$ \\
& Nudged gilt & $5 / 5$ & $5 / 5$ & $5 / 5$ \\
& Mounted gilt & $2 / 5$ & $3 / 5$ & $2 / 5$ \\
& Pelvic thrusts & $2 / 5$ & $0 / 5$ & $2 / 5$ \\
& Penis extruded & $0 / 5$ & $0 / 5$ & $0 / 5$ \\
\hline
\end{tabular}

\section{Discussion}

The hypertrophy of the prostate and seminal vesicles in pigs receiving oestrone, which was due to the increase in fibrous stromal tissue and not the secretory epithelium, agrees with previous findings in the guinea-pig (Davies \& Danzo, 1981 ; Neubauer \& Mawhinney, 1981), rat (Corrales, 
Hoisaeter, Kadohama, Murphy \& Sandberg, 1981), rabbit (Bern, 1949; Beyer, de la Torre, Larsson \& Perez-Palacios, 1975; Foote, Draddy, Breite \& Oltenacu, 1977) and horse (Thompson, Pickett, Squires \& Nett, 1980). The enlargement of the muscle surrounding the urethra, together with the excess fibrous stromal tissue in the accessory sex glands, would appear to be an expression of an anabolic effect of oestrone rather than an 'androgenic' effect. These results, however, contrast with those in an earlier study (Booth, 1980) in which no specific effects of oestrone were found in castrated boars treated with oestrone and an androgen. One possible explanation for this difference could be that testosterone and 5-androstenediol had an inhibitory effect on the oestrogen. This is supported by the observation that the pigs receiving androgen and oestrone initially developed large teats which regressed before the end of the experiment, whereas in the present study pigs treated with oestrone alone had enlarged teats throughout the course of treatment.

Minces of the prostate and seminal vesicles of mature intact boars more readily converted oestrone to oestradiol-17 $\beta$ rather than vice versa (Booth, 1983), which is in keeping with the pattern for oestrogen metabolism in oestrogen target organs and the hypertrophy of the accessory sex glands in the present study. Furthermore, the minces also converted DHA primarily to weak androgens (androstenedione and its $5 \alpha$-reduced metabolites $5 \alpha$-androstanedione and androsterone), rather than to the potent androgens testosterone and its $5 \alpha$-reduced metabolites, which is in keeping with the failure of DHA to support the growth of the accessory sex organs in vivo. An indicator of the lack of secretory epithelium in the seminal vesicles of pigs treated with DHA and oestrone was the very low concentration of zinc in the glands; these findings are similar to those for untreated castrated boars (Booth, 1980).

The weights and histology of the submaxillary glands of the steroid-treated pigs indicated that these glands had not been affected by DHA or oestrone, and the data are in keeping with the results of earlier work (Booth, 1980). However, the submaxillary glands of the unilaterally castrated, unilateral cryptorchid pig were nearly twice as large as those in the other steroid-treated pigs, and supports the concept that the testis is important for the hypertrophy of the submaxillary gland of the pig (Booth, Hay \& Dott, 1973; Booth \& Polge, 1976).

The levels of steroids in the peripheral plasma of the steroid-treated pigs complemented the morphological and behavioural effects that were found. The castrated pigs treated with DHA had lower amounts of plasma DHA than did intact boars. Furthermore, DHA, in contrast to 5androstenediol (Booth, 1980), did not give rise to increased levels of unconjugated androgen in the peripheral plasma of castrated boars. Failure of DHA to have an androgenic effect would not appear to be due to conjugation of the steroid as DHA sulphate, since this steroid conjugate was undetectable in the plasma of the DHA-treated pigs. The values for DHA and DHA sulphate in the peripheral plasma of intact boars in the present study are similar to those determined by Setchell $e t$ al. (1983), using the same radioimmunoassay method, and by Booth (1980) with a gas-liquid chromatography method. Unconjugated oestrogen in the plasma of the oestrone-treated boars was 5-fold higher than that in intact boars, and 2-3-fold higher than that found previously in castrated boars treated with androgen and oestrone (Booth, 1980). These higher values were probably due to the fact that blood was collected on the day after an injection of oestrone, in this study, and 2 days after an injection in the work by Booth (1980). In the present work the level of unconjugated oestrogen in plasma 6 days after a double injection of oestrone in this study was similar to that found 2 days after treatment with oestrone in the previous study.

The general failure of DHA to support male behaviour in castrated boars is comparable to that found when 5-androstenediol was administered to castrated boars (Booth, 1980). An explanation for this finding is that these 5-ene unsaturated $\mathrm{C}_{19}$ steroids are not direct androgen substrates for aromatization to oestrogen in brain tissues (Naftolin et al., 1975) which seems to be an important prerequisite for the expression of male behaviour in some species. The behavioural responses which occurred after the introduction of DHA-treated pigs to oestrous gilts were similar to those seen when strange gilts or castrates are mixed, i.e. behaviour ranging from avoidance to various degrees of aggression. However, the castrated pigs receiving oestrone displayed some 
characteristics of male mating behaviour. This is in contrast to the findings of Ford (1982) who found that prepubertally castrated boars treated with oestradiol benzoate post-pubertally only expressed female mating behaviour. The present work indicates, therefore, that oestrogen is necessary during puberty in the male pig for sexual differentiation of those regions in the brain responsible for male behaviour. The ability of oestrone to support some aspects of male mating behaviour, but not penile extrusion or ejaculation in the prepubertally castrated pig is similar to that found in the gelding (Thompson et al., 1980) and ram (D'Occhio \& Brooks, 1980). Potent androgens such as testosterone (Booth, 1980) and possibly $5 \alpha$-dihydrotestosterone seem to be necessary for full penile erection and ejaculation in the boar as well as in the ram (Parrott, 1978; D'Occhio \& Brooks, 1980) and rat (Bradshaw, Baum \& Awh, 1981).

In conclusion, although DHA and 5-androstenediol are major secretory products of the boar testis, DHA is unlikely to have any significant influence on the accessory sex glands, in contrast to 5-androstenediol; this may be due to the fact that DHA is not an immediate precursor of testosterone. However, the present study and that of Joshi \& Raeside (1973) indicate that oestrone is likely to be a hormone in the boar, involved in both male behaviour and accessory sex gland function. Since oestrogen stimulates the development of fibromuscular tissue in the accessory sex glands, this tissue may function synergistically with the secretory tissue supported by certain androgens to expel the secretions of the glands. Oestrone may also modulate the autonomic nervous system by facilitating its role in the production of accessory organ secretion. Support for this concept arises from the fact that the castrated boars treated with oestrone produced excess saliva when aroused.

I thank Miss Carol White for able technical assistance, Mr A. Jones, Mr L. Smith and Mr J. Doggett for assistance with the pigs, and the Meat \& Livestock Commission for the carcass evaluations. I am also grateful to Dr A. P. F. Flint for the antiserum to DHA and DHA sulphate.

\section{References}

Baulieu, E.E., Fabre-Jung, I. \& Huis in't Veld, L.G. (1967) Dehydroepiandrosterone sulfate: a secretory product of the boar testis. Endocrinology 81, 34-38.

Bern, H.A. (1949) The effects of sex steroids on the sex accessories in the male Dutch rabbit. Am. J. Anat. 84, 231-277.

Beyer, C., de la Torre, L., Larsson, K. \& Perez-Palacios, G. (1975) Synergistic actions of oestrogen and androgen on the sexual behaviour of the castrated rabbit. Horm. Behav. 6, 301-306.

Booth, W.D. (1975) Changes with age in the occurrence of $\mathrm{C}_{19}$ steroids in the testis and submaxillary gland of the boar. J. Reprod. Fert. 42, 459-472.

Booth, W.D. (1977) Metabolism of androgens in vitro by the submaxillary salivary gland of the mature domestic boar. $J$. Endocr. 75, 145-154.

Booth, W.D. (1980) A study of some major testicular steroids in the pig in relation to their effect on the development of male characteristics in the prepubertally castrated boar. J. Reprod. Fert. 59, 155-162.

Booth, W.D. (1982) Testicular steroids and boar taint. In Control of Pig Reproduction, pp. 25-48. Eds D. J. A. Cole \& G. R. Foxcroft. Butterworths, London.

Booth, W.D. (1983) In-vitro metabolism of unconjugated androgens, cestrogens and the sulphate conjugates of androgens and oestrone by accessory sex organs of the mature domestic boar. J. Endocr. 96, 457-464.
Booth, W.D. \& Baldwin, B.A. (1980) Lack of effect on sexual behaviour or the development of testicular function after removal of olfactory bulbs in prepubertal boars. J. Reprod. Fert. 58, 173-182.

Booth, W.D. \& Polge, C. (1976) The occurrence of $C_{19}$ steroids in testicular tissue and submaxillary glands of intersex pigs in relation to morphological characteristics. J. Reprod. Fert. 46, 115-121.

Booth, W.D., Hay, M.F. \& Dott, H.M. (1973) Sexual dimorphism in the submaxillary gland of the pig. $J$. Reprod. Fert. 33, 163-166.

Bradshaw, W.G., Baum, M.J. \& Awh, C.C. (1981) Attenuation by a $5 \alpha$-reductase inhibitor of the activational effect of testosterone propionate on penile erections in castrated male rats. Endocrinology 109, 1047-1051.

Claus, R. \& Hofimann, B. (1980) Oestrogens compared to other steroids of testicular origin in blood plasma of boars. Acta endocr., Copenh. 94, 404 411.

Corrales, J.J., Hoisaeter, P.A., Kadohama, N., Murphy, G.P. \& Sandberg, A.A. (1981) A model for studies on the response of the ventral prostate to oestrogens. Acta endocr., Copenh. 97, 125-136.

Davies, J. \& Danzo, B.J. (1981) Hormonally responsive areas of the reproductive system of the male pig. II. Effects of estrogens. Biol. Reprod. 25, 11491158. 
D'Occhio, M.J. \& Brooks, D.E. (1980) Effects of androgenic and oestrogenic hormones on mating behaviour in rams castrated before and after puberty. J. Endocr. 86, 403-411.

Foote, R.H., Draddy, P.J., Breite, M. \& Oltenacu, E.A.B. (1977) Action of androgen and estrone implants on sexual behavior and reproductive organs of castrated male rabbits. Horm. Behav. 9, 57-68.

Ford, J.J. (1982) Testicular control of defeminization in male pigs. Biol. Reprod. 27, 425-430.

Henricks, D.M., Guthrie, H.D. \& Handlin, D.L. (1972) Plasma estrogen, progesterone and luteinizing hormone levels during the estrous cycle in pigs. Biol. Reprod. 6, 210-218.

Joshi, H.S. \& Raeside, J.I. (1973) Synergistic effects of testosterone and oestrogen on accessory sex glands and sexual behaviour of the boar. J. Reprod. Fert. 33, $411-423$.

Naftolin, F., Ryan, K.J., Davies, I.J., Reddy, V.V., Flores, F., Petro, Z., Kuhn, M., White, R.J., Takaoka, Y. \& Wolin, L. (1975) The formation of estrogens by central neuroendocrine tissues. Recent Prog. Horm. Res. 31, 295-319.

Neubauer, B. \& Mawhinney, M. (1981) Actions of androgen and estrogen on guinea pig seminal vesicle epithelium and muscle. Endocrinology 108, 680-687.

Newcomb, R., Booth, W.D. \& Rowson, L.E.A. (1977) The effect of oxytocin treatment on the levels of prostaglandin $\mathrm{F}$ in the blood of heifers. J. Reprod. Fert. 49, 17-24.

Oh, R. \& Tamaoki, B. (1973) In-vitro biosynthesis of androgens in canine testes. Acta endocr., Copenh. 74, 615-624.

Parrott, R.F. (1978) Courtship and copulation in prepubertally castrated male sheep (wethers) treated with $17 \beta$-estradiol, aromatizable androgens, or dihydrotestosterone. Horm. Behav. 11, 20-27.

Pashen, R.L., Sheldrick, E.L., Allen, W.R. \& Flint, A.P.F. (1982) Dehydroepiandrosterone synthesis by the fetal foal and its importance as an oestrogen precursor. $J$. Reprod. Fert., Suppl. 32, 389-397.

Raeside, J.I. \& Howells, G.A. (1971) The isolation and identification of androstenediol sulfate from the spermatic vein blood and testes of the boar. Can. $J$. Biochem. 49, 80-84.

Ruokonen, A. (1978) Steroid metabolism in testis tissue: the metabolism of pregnenolone, pregnenolone sulfate, dehydroepiandrosterone and dehydroepiandrosterone sulfate in human and boar testes in vitro. $J$. Steroid Biochem. 9, 939-946.

Ruokonen, A. \& Vihko, R. (1974) Steroid metabolism in testis tissue: concentration of unconjugated and sulfated neutral steroids in boar testis. J. Steroid Biochem. 5, 33-38.

Setchell, B.P., Laurie, M.S., Flint, A.P.F. \& Heap, R.B. (1983) The transport of free and conjugated steroids from the boar testis in lymph, venous blood and rete testis fluid. J. Endocr. 96, 127-136.

Smith, M.R., Rudd, B.T., Shirley, A., Rayner, P.H.W., Williams, J.W., Duignan, N.M. \& Bertrand, P.V. (1975) A radioimmunoassay for the estimation of serum dehydroepiandrosterone sulphate in normal and pathological sera. Clin. Chim. Acta 65, 5-13.

Thompson, D.L., Pickett, B.W., Squires, E.L. \& Nett, T.M. (1980) Sexual behavior, seminal $\mathrm{pH}$ and accessory sex gland weights in geldings administered testosterone and (or) estradiol-17ß. J. Anim. Sci. 51, $1358-1366$.

Velle, W. (1966) Urinary oestrogens in the male. $J$. Reprod. Fert. 12, 65-73.

Vihko, R. \& Ruokonen, A. (1975) Steroid sulphates in human adult testicular steroid synthesis. J. Steroid Biochem. 6, 353-356.

Yamaji, T., Motohashi, K., Tanioka, T. \& Ibayashi, H. (1968) Androstenediol in canine spermatic vein blood and its significance in testosterone biosynthesis in vivo. Endocrinology 83, 992-998.

Received 6 July 1982 